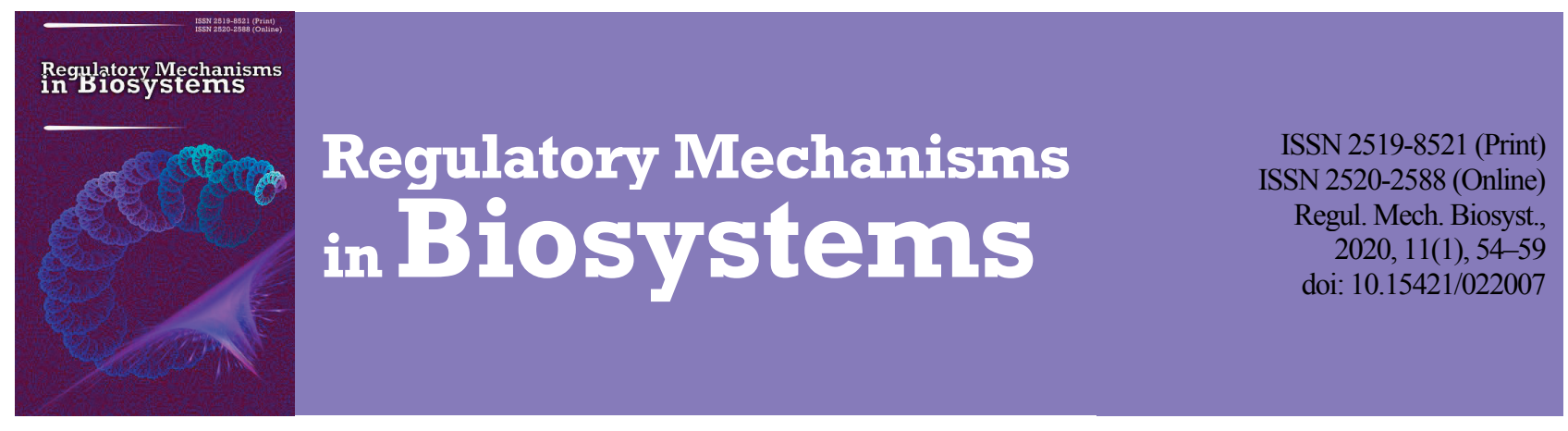

\title{
The effect of additive containing an organic form of iodine on the physiological-biochemical parameters of the body of cows
}

\author{
A. A. Bogdanova*, A. A. Alekseev*, E. A. Flerova*, **, A. V. Konovalov* \\ *Yaroslavl Scientific Research Institute of Livestock Breeding and Forage Production - Federal State Budget Scientific Institution \\ "Federal Williams Research Center of Forage Production and Agroecology", Mihajlovskij, Russia \\ **P. G. Demidov Yaroslavl State University, Yaroslavl, Russia
}

\author{
Article info \\ Received 14.01.2020 \\ Received in revised form \\ 10.02 .2020 \\ Accepted 12.02.2020 \\ Yaroslavl Scientific \\ Research Institute of \\ Livestock Breeding and \\ Forage Production - \\ Federal State Budget \\ Scientific Institution \\ "Federal Williams Research \\ Center of Forage Production \\ and Agroecology", \\ Lenina st., 1, Mihajlovskij, \\ 150517, Yaroslavskaja \\ oblast, Russia. \\ Tel.: 48-52-437-567. \\ E-mail:yaniizhk@yandex.ru \\ P. G. Demidov Yaroslavl \\ State University, \\ Sovetskaya st., 14 \\ Yaroslavl, 150003, Russia \\ Tel.: 48-52-797-702. \\ E-mail: \\ rectorat@univar.ac.ru
}

\begin{abstract}
Bogdanova, A. A., Alekseev, A. A., Flerova, E. A., \& Konovalov, A. V. (2020). The effect of additive containing an organic form of iodine on the physiological-biochemical parameters of the body of cows. Regulatory Mechanisms in Biosystems, 11(1), 54-59. doi:10.15421/022007
\end{abstract}

Iodine deficiency in soil and water in many countries leads to its low content in plants and animal feed produced from them. The limited intake of this element in animals can lead to endemic diseases. The lack of iodine in animal feeding is most often compensated for by the use of additives with an inorganic form of iodine, which can be poorly absorbed by the body. Feed products with an organic form of iodine have a great biological effect. A study on the effect of iodine-containing additives on the physiological and biochemical parameters of the animal organism was carried out on two groups of 15 cows. The experimental group was fed an organic form of iodine as part of the additive, the control group received an inorganic form of iodine. For all animals during the experiment the biochemical parameters of blood, milk productivity and reproductive ability were studied. During the experiment, an increase in metabolic and redox processes in the body was noted in the experimental group. An increase in mineral metabolism, including iodine content, was found. Due to the sufficient intake of organic iodine in the animals of the experimental group, there was an increase in the activity of the main hepatic enzymes AST and ALT. An increase in the process of gluconeogenesis due to an increase in the glucose content in the blood of experimental cows was revealed. An increase in milk production and reproductive function of animals of the experimental group was established. Within 30 days after the termination of feeding the supplement with the organic form of iodine in the experimental group, a prolonging effect was observed, consisting in higher values of blood biochemical parameters, improved reproductive function and milk productivity relative to equivalent animals in the control. As a result, it was concluded that the use of an additive with an organic form of iodine in the amount of $1.5 \mathrm{~g}$ in feeding cows for 60 days increases the iodine content in the blood serum of animals and increases the performance of all types of metabolism, which may indicate the best stimulating effect of the organic form of iodine on thyroid activity glands. This in turn helps to improve the productive and reproductive qualities of animals. To recommend the studied drug as a means to replenish iodine deficiency in animals and to more accurately analyze its effect on the hormone-forming function of the thyroid gland, it is necessary to study the level of thyroid hormones in the blood.

Keywords: iodine deficiency; thyroid function; blood counts; reproductive function; metabolic processes.

\section{Introduction}

Stable increase in the production of livestock products requires well-organized provision of a nutritious and balanced diet to agricultural animals, one of the main factors of which is satisfaction of the organism's requirement for mineral substances. Insufficient and excessive intake of macro- and microelements has an inhibiting effect on the organisms of animals, decreasing their growth rates, productive qualities and causing various diseases (Hunchak et al., 2018). One of the vital microelements for the organisms of animals and humans is iodine (Voogt et al., 2010; Rasmussen et al., 2011; Hu et al., 2012; Flachowsky et al., 2014; Weng et al., 2014). Many scientists have noted the deficiency of this component in the soil and water in different countries. Iodine deficiency is observed in Africa, Asia, and also most of the world's developed industrial centers such as the Russian Federation and Austria, New Zealand, USA and Europe, which is reflected in the iodine concentration in plants and animal fodders made from them (Hu et al., 2012; Leung et al., 2012; Fuge, 2013; Vavilina \& Rybkin, 2013). Organic introduction of iodine with the main diet into the organism of animals can cause malfunctioning of the thyroid as a result of insufficient formation of thyroxine hormone, which in turn leads to the development of endemic diseases, reduction of productive qualities, and decrease in the reproductive ability of animals (Nudda et al., 2009; Pattanaik et al., 2011; Rasmussen et al., 2011; Zimmermann \& Boelaert, 2015).

To solve this problem, currently, in the feeding of agricultural animals, most often the non-organic form of iodine is used as an iodinecontaining component of mineral additives. In such form iodine is unstable and can oxidize, leading to decrease in its content in the feeds. Moreover, during the use of non-organic iodine in mineral mixes, it can take part in reactions with biologically active substances and form compounds which the organism is unable to digest (Vereshchak et al., 2012; Liu et al., 2015; Petrov \& Gnezdilova, 2015). This way of including iodine in the diet makes the control of its ingression into the organism of animals impossible. As an alternative source of iodine, it is possible to use organic compounds of this element in which iodine is bound to a protein or amino-acid. Digestion of iodine present within such complexes is controlled by the system of homeostasis. This contributes to the cleavage of this microelement depending on the organism's requirement for it, and the excesses of organic iodine are removed naturally (Vereshchak et al., 2012; Gorlov et al., 2014; Rey-Crespo et al., 2014).

The biochemical control of the satisfaction of animals' requirements for iodine requires study of physiologic-biochemical parameters. Cur- 
rently, there are data on the impact of fodder additives which contain non-organic and organic forms of iodine on the organisms of cattle. Nonetheless, their effect on the biochemical parameters of blood, reproductive functions and dairy productivity of animals is studied insufficiently.

The objective of our studies was the impact of iodine-containing preparations on the physiologic-biochemical parameters of the organism of lactating cows.

\section{Materials and methods}

For the research, carried out at the PLC Agrofirm Pahma of Yaroslavsky District, using the method of pair analogues, in the period of milking, control (I) and experimental (II) groups of Ayrshire cows were formed, each containing 15 individuals. They were kept in stanchiontied stables during the winter stall period.

The animals of the control and experimental groups received a daily diet, including (kg/individual): cereal-legume silage - 12, maize silage 13 , cereal hay -1 , combined fodder -10 , flattened grain -1 ; soybean grist 2 , premix -0.1 , barley hay -1 , salt -0.12 , monocalcium phosphate -0.05 ; fodder chalk -0.05 . The nutrition value of the diet equaled $257.6 \mathrm{~mJ}$. The diets corresponded to the norm for this age period (Kalashnikov, 2003). Together with the main diet and water, the cows received $10.43 \mathrm{mg}$ of iodine per individual a day, equaling $0.45 \mathrm{mg}$ of iodine per $1 \mathrm{~kg}$ of dry matter of the diet at the norm of $0.88-1.00 \mathrm{mg}$ of iodine per $1 \mathrm{~kg}$ of dry matter of the diet (Kalashnikov, 2003, Romanenko et al., 2014).

As an additional source of iodine, non-organic iodine is used, which contains iodine potassium. The daily norm of this preparation for one animal was two tablets of $0.2 \mathrm{mg}$ each according to the recommendations for this preparation. Over 30 days of the preparation period, both groups of lactating cows received the basic diet with potassium iodine (Technical Conditions 9347-016-46811620-2008), and in the following 60 days the animals of the experimental group were given feed with organic form of iodine instead of potassium iodine, and the control group continued to receive the same diet. In the final period (19-120th days) all the animals of both groups were fed with the basic diet with potassium iodine and the effect of the consequences of adding organic iodine-containing feed was studied (Table 1). Feeding with the fodder in the form of powder and potassium iodine in the form of tablets was carried out manually once a day during the morning feeding together with the basic diet. The amount of feed with organic iodine was calculated following the recommendations of the USA "Nutrient Requirements of Dairy Cattle" (National Research Council et al. Nutrient requirements of dairy cattle, 2001) and the All-Russia Research Institute for Animal Husbandry (VIZh) (Kalashnikov et al., 2003). Because $1 \mathrm{~g}$ of feed contains no less than $7 \mathrm{mg}$ of organic iodine, the daily dose of it was estimated at $1.5 \mathrm{~g}$ per animal.

Table 1

Scheme of the experiment

\begin{tabular}{|c|c|c|c|c|}
\hline \multirow{2}{*}{$\begin{array}{c}\text { Gro- } \\
\text { up }\end{array}$} & & \multicolumn{3}{|c|}{ Period } \\
\hline & & $1-30^{\text {th }}$ days & main, $31-90^{\text {th }}$ days & final, $91-120^{\text {th }}$ days \\
\hline I & 15 & $\begin{array}{c}\mathrm{BD}+\text { potassium } \\
\text { iodine }(0.4 \mathrm{~g} / \text { ind./day })\end{array}$ & $\begin{array}{c}\mathrm{BD}+\text { potassium } \\
\text { iodine }(0.4 \mathrm{~g} / \text { ind./day })\end{array}$ & $\begin{array}{c}\mathrm{BD}+\text { potassium } \\
\text { iodine }(0.4 \mathrm{~g} / \text { ind./day })\end{array}$ \\
\hline II & 15 & $\begin{array}{c}\mathrm{BD}+\text { potassium } \\
\text { iodine }(0.4 \mathrm{~g} / \text { ind } / \text { day })\end{array}$ & $\begin{array}{c}\mathrm{BD}+\text { feed containg } \\
\text { organic iodinea } \\
(1.5 \mathrm{~g} / \text { ind./day })\end{array}$ & $\begin{array}{c}\mathrm{BD}+\text { potassium } \\
\text { iodine }(0.4 \mathrm{~g} / \text { ind./day })\end{array}$ \\
\hline
\end{tabular}

Note: BD-basic diet.

In the control and experimental groups, on the 1st, 30th, 60th, 90th and 120th days, before the morning feeding, blood from the jugular vein was taken for determining the biochemical parameters. Activity of alkaline phosphatase, amount of urea, magnesium, phosphorus, total protein, cholesterol, albumin, activity of alanine aminotransferase (ALT) and aspartate aminotransferase (AST), and the level of glucose in blood serum were determined using a STAT FAX 3300 biochemical analyzer with Diakon (Russia) and Vektor-Best (Russia) reagents kits. Calcium in the blood serum was determined using the complexometric method with indicator of fluorescein according to Vichev, Karakashev, the reserve alkalinity in blood serum was determined using the diffuse method with two flasks interconnected by a tube, and carotene in blood serum was determined according to Karp and Preis as modified by Yudkin (Kondrahin, 2004), the protein index was calculated, and iodine in blood serum was determined using the method of mass-spectrometry with inductively bond argon plasma. De Ritis coefficient was calculated as ratio of AST to ALT.

Record and evaluation of dairy productivity of lactating cows of both groups were performed by estimation of daily milking according to the data of monthly control milking made during the experiment. Physical-chemical properties of milk: dry matter, contents of fat, protein, lactose and the number of somatic cells were determined using a BentleyCombi 150 analyzer.

During the evaluation of reproductive ability of the cows we considered the following parameters: the number of days before the first insemination, percentage of the animals inseminated over the first 90 days, service-period, index of insemination (number of inseminations necessary for productive insemination). In the study we used the data of zootechnical control.

The results were statistically analyzed in Statistica program (Stat Soft Inc., USA). For the evaluation of the surveyed parameters we used statistical methods. We calculated the mean arithmetic value and the standard error. The differences between the values in the control and experimental groups were determined using ANOVA, where the differences were considered reliable at $\mathrm{P}<0.05$. The results were determined as mean \pm standard error $(\mathrm{x} \pm \mathrm{SE})$.

\section{Results}

The parameters of the protein metabolism of lactating cows of the experimental and control groups were within the physiological norm (Table 2). During the course of the experiment, on the 90th day we observed a reliable increase in the parameter of total protein in blood serum of the animals which received organic form of iodine in the content of feed with organic form of iodine, which remained also on the 120 th day $(\mathrm{P}<0.05)$. Increase in the content of total protein in lactating cows of the experimental group occurred as a result of rise of the level of albumin by $15.4 \%$ and $7.9 \%$ on the 90 th and 120 th days respectively $(\mathrm{P}<0.05)$ compared with the parameters of animals of the control group. As a result, on the 60th day of the experiment the coefficient of ratio of albumin and globulin or protein index in the experimental group of animals exceeded this parameter of the cows in the I group by $1.7 \%$, and by the 90th and 120th days it was higher than such in the control by 14.5 and $7.0 \%$ respectively $(\mathrm{P}<0.05$, Table 2$)$.

Research on the mineral metabolism in the animals that took part in the experiment did not reveal deviations in the surveyed parameters from the physiological norm (Table 3). It should be noted that the content of iodine in the blood serum of animals of the experimental group exceeded the value of this parameter in the control on the 90th and 120th days of the experiment by 13.4 and $8.8 \%$ respectively $(\mathrm{P}<0.05)$. On the 90th day of the experiment, in the blood of lactating cows, the level of phosphorus increased by $7.4 \%$, equaling $5.9 \%$ on the 120 th or 30th days after feeding the animals with the organic iodine compared with the data of the control group.

As a result of our studies, we found no deviations from the values of the physiological norm of the parameters of activity of the enzymes in the blood serum of animals from the experimental and control groups (Table 4). On the 90th day of the experiment, in the blood serum of animals which received organic iodine, we observed increase in the parameter of alanine aminotransferase (ALT) by $11.6 \%$ compared with such value in the cows of the control group. On the 120th day, the experimental group was observed to have a significant increase in the activity of ALT equaling $16.5 \%$ compared with the parameter of the control.

On the 30th day after feeding with organic iodine was stopped, the animals of the II group were determined to have a decrease in the values of the de Ritis ratio equaling $13.5 \%$ compared with the parameter of the control group. The value of the alkaline phosphatase in animals of the II group of lactating cows increased by $11.3 \%$ on the 90 th day compared with the animals of the I group, on the 120th day this tendency was maintained, the difference from the same parameter of the control group equaled $11.1 \%(\mathrm{P}<0.05)$. 
Table 2

Parameters of protein metabolism $(x \pm S E, n=15)$

\begin{tabular}{|c|c|c|c|c|c|c|}
\hline Period of the experiment & Group & Total protein, $\mathrm{g} / \mathrm{L}$ & Albumin, $\mathrm{g} / \mathrm{L}$ & Globulin, g/L & Protein index & Urea, $\mathrm{mmol} / \mathrm{L}$ \\
\hline \multirow{2}{*}{ On the $1^{\text {st }}$ day } & I & $75.51 \pm 1.62$ & $28.81 \pm 0.48$ & $46.70 \pm 1.19$ & $0.617 \pm 0.013$ & $3.89 \pm 0.26$ \\
\hline & II & $74.73 \pm 1.22$ & $28.56 \pm 0.53$ & $46.17 \pm 1.13$ & $0.621 \pm 0.020$ & $3.70 \pm 0.11$ \\
\hline \multirow{2}{*}{ On the $30^{\text {th }}$ day } & I & $73.32 \pm 1.64$ & $28.09 \pm 0.32$ & $45.23 \pm 1.60$ & $0.621 \pm 0.026$ & $4.33 \pm 0.29$ \\
\hline & II & $72.28 \pm 2.88$ & $28.60 \pm 1.89$ & $43.68 \pm 1.67$ & $0.655 \pm 0.031$ & $4,31 \pm 0.39$ \\
\hline \multirow{2}{*}{ On the $60^{\text {th }}$ day } & I & $72.30 \pm 2.14$ & $28.43 \pm 0.88$ & $43.87 \pm 1.39$ & $0.648 \pm 0.032$ & $4.51 \pm 0.36$ \\
\hline & II & $75.27 \pm 1.69$ & $29.89 \pm 1.52$ & $45.38 \pm 2.22$ & $0,659 \pm 0.028$ & $4.48 \pm 0.28$ \\
\hline \multirow{2}{*}{ On the $90^{\text {th }}$ day } & I & $73.44 \pm 0.72$ & $28.50 \pm 0.44$ & $44.94 \pm 0.56$ & $0.634 \pm 0.014$ & $4.21 \pm 0.19$ \\
\hline & II & $78.19 \pm 0.67 *$ & $32.89 \pm 0.54^{*}$ & $45.30 \pm 0.61$ & $0.726 \pm 0.015^{*}$ & $4.22 \pm 0.24$ \\
\hline \multirow{2}{*}{ On the $120^{\text {th }}$ day } & I & $73.45 \pm 1.09$ & $28.30 \pm 0,47$ & $45.15 \pm 1.03$ & $0.627 \pm 0.018$ & $4.53 \pm 0.29$ \\
\hline & II & $76.08 \pm 0.83^{*}$ & $30.54 \pm 0.18^{*}$ & $45.54 \pm 0.74$ & $0.671 \pm 0.017^{*}$ & $4.24 \pm 0.31$ \\
\hline
\end{tabular}

Note: $* \mathrm{P}<0.05$ compared with the parameters of the control group.

Table 3

Parameters of mineral metabolism $(\mathrm{x} \pm \mathrm{SE}, \mathrm{n}=15)$

\begin{tabular}{|c|c|c|c|c|c|c|}
\hline Period of the experiment & Groups & $\mathrm{I}, \mu \mathrm{g} / \mathrm{mL}$ & $\mathrm{Mg}, \mathrm{mmol} / \mathrm{L}$ & $\mathrm{P}, \mathrm{mmol} / \mathrm{L}$ & $\mathrm{Ca}, \mathrm{mmol} / \mathrm{L}$ & Reserve alkalinity, $\%$ \\
\hline \multirow{2}{*}{ On the $1^{\text {st }}$ day } & $\mathrm{I}$ & $0.074 \pm 0.005$ & $1.08 \pm 0.06$ & $1.66 \pm 0.12$ & $2.74 \pm 0.11$ & $55.1 \pm 0.3$ \\
\hline & II & $0.075 \pm 0.004$ & $1.19 \pm 0.08$ & $1.67 \pm 0.09$ & $2.70 \pm 0.07$ & $54.9 \pm 0.3$ \\
\hline \multirow{2}{*}{ On the $30^{\text {th }}$ day } & $\mathrm{I}$ & $0.079 \pm 0.003$ & $1.15 \pm 0.01$ & $1.73 \pm 0.08$ & $2.79 \pm 0.05$ & $52.4 \pm 0.8$ \\
\hline & II & $0.078 \pm 0.004$ & $1.11 \pm 0.03$ & $1.64 \pm 0.09$ & $2.74 \pm 0.03$ & $53.4 \pm 0.5$ \\
\hline \multirow{2}{*}{ On the $60^{\text {th }}$ day } & $\mathrm{I}$ & $0.083 \pm 0.007$ & $1.09 \pm 0.01$ & $1.65 \pm 0.10$ & $2.73 \pm 0.04$ & $53.1 \pm 0.4$ \\
\hline & II & $0.089 \pm 0.004$ & $1.12 \pm 0.03$ & $1.71 \pm 0.07$ & $2.76 \pm 0.06$ & $53.8 \pm 0.5$ \\
\hline \multirow{2}{*}{ On the $90^{\text {th }}$ day } & I & $0.082 \pm 0.003$ & $1.06 \pm 0.04$ & $1.63 \pm 0.07$ & $2.71 \pm 0.06$ & $54.3 \pm 1.1$ \\
\hline & II & $0.093 \pm 0.004^{*}$ & $1.15 \pm 0.06$ & $1.75 \pm 0.09$ & $2.73 \pm 0.05$ & $55.8 \pm 0.9$ \\
\hline \multirow{2}{*}{ On the $120^{\text {th }}$ day } & I & $0.080 \pm 0.003$ & $1.03 \pm 0.06$ & $1.70 \pm 0.07$ & $2.65 \pm 0.09$ & $54.4 \pm 0.6$ \\
\hline & II & $0.087 \pm 0.003^{*}$ & $1.10 \pm 0.01$ & $1.80 \pm 0.07$ & $2.70 \pm 0.08$ & $55.6 \pm 0.5$ \\
\hline
\end{tabular}

Note: see Table 2.

Table 4

Parameters of activity of enzymes $(x \pm S E, n=15)$

\begin{tabular}{cccccc}
\hline $\begin{array}{c}\text { Period } \\
\text { of the } \\
\text { experiment }\end{array}$ & $\begin{array}{c}\text { Gro- } \\
\text { ups }\end{array}$ & AST, U/L & ALT, U/L & $\begin{array}{c}\text { De Ritis ratio } \\
\text { (AST/ALT) }\end{array}$ & $\begin{array}{c}\text { Alkaline phos- } \\
\text { phatase, U/L }\end{array}$ \\
\hline $1^{\text {st }}$ day & I & $63.2 \pm 4.9$ & $22.5 \pm 2.2$ & $2.81 \pm 0.22$ & $116.6 \pm 10.1$ \\
& II & $61.9 \pm 5.6$ & $22.3 \pm 3.3$ & $2.78 \pm 0.81$ & $121.3 \pm 6.8$ \\
$30^{\text {th }}$ day & I & $62.1 \pm 7.7$ & $21.1 \pm 1.6$ & $2.94 \pm 0.36$ & $97.1 \pm 9.9$ \\
& II & $63.4 \pm 7.8$ & $21.9 \pm 2.1$ & $2.89 \pm 0.43$ & $91.3 \pm 3.9$ \\
$60^{\text {th }}$ day & I & $63.9 \pm 7.7$ & $21.5 \pm 1.0$ & $2.97 \pm 0.41$ & $100.4 \pm 7.4$ \\
& II & $64.5 \pm 4.2$ & $23.5 \pm 2.4$ & $2.74 \pm 0.48$ & $104.3 \pm 5.4$ \\
$90^{\text {th }}$ day & I & $64.5 \pm 6.5$ & $21.6 \pm 1.1$ & $2.98 \pm 0.26$ & $103.1 \pm 4.2$ \\
& II & $64.2 \pm 4.8$ & $24.1 \pm 3.6$ & $2.66 \pm 0.28$ & $114.7 \pm 2.9^{*}$ \\
$120^{\text {th }}$ day & I & $64.7 \pm 4.3$ & $23.6 \pm 1.7$ & $2.74 \pm 0.37$ & $105.9 \pm 6.0$ \\
& II & $65.1 \pm 3.7$ & $27.5 \pm 1.6^{*}$ & $2.37 \pm 0.32$ & $117.7 \pm 5.1^{*}$ \\
\hline
\end{tabular}

Note: $* \mathrm{P}<0.05$ at comparison with the parameters of the control group.

The level of glucose in the animals of the II group exceeded the same parameter in the animals of the control group by $3.1 \%$ and $2.3 \%$ on the 60th and 90th days of the experiment respectively (Fig. 1). According to the data of our research, the content of cholesterol in blood serum of cows of the experimental group was lower by $10.9 \%$ on the 60 th and on the 90th day reliably reduced by $16.9 \%$ compared with the control $(\mathrm{P}<0.05)$, and on the 120th day the decrease in this parameter accounted for $6.1 \%$ compared with the control (Fig. 2).

As a result of feeding with organic iodine, the lactating cows of the II group were observed to have an increase in the content of carotene by $9.1 \%$ on the 60th day and $10.3 \%$ on the 90 th day of the study, and on the 120th the value of this parameter was $10.6 \%$ compared with the data of the control group $(\mathrm{P}<0.05$; Fig. 3$)$.

According to the results of our studies, by the 60th day of the experiment, mass of the share of fat in both groups of cows increased (Table 5). The number of the somatic cells (NSC) in the milk of animals in the experiment did not exceed the allowable normative values. We should note that in the milk of animals which received organic iodine this parameter decreased by $19.1 \%$ and $28.4 \%$ on the 60 th and 90 th days respectively. This tendency was observed also on the 30th day after termination of providing feed containing the organic iodine.

Percentage of the inseminated animals after the first insemination comprised $60 \%$ in the experimental group of animals and $46.7 \%$ in the control. Analysis of the duration of the service-period revealed that in animals which received organic iodine this parameter accounted for 88 days on average and in the animals of the control - 95.5 days, and a positive tendency towards duration of service-period was seen in the experimental group. It was determined that the index of insemination in the lactating cows of the II group was reliably lower than such in animals of the control group and accounted for 1.6 $(\mathrm{P}<0.05)$.

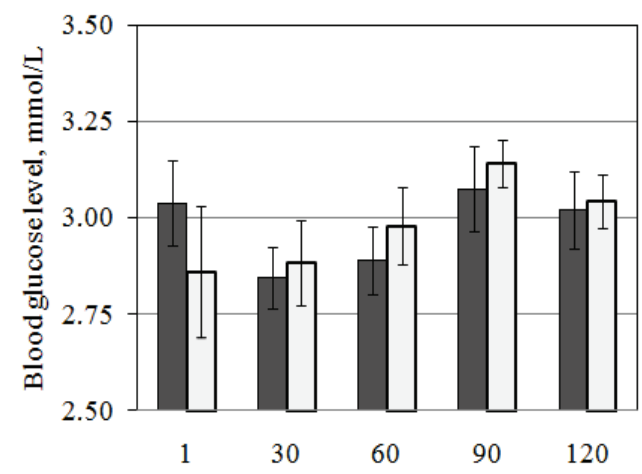

Fig. 1. The level of glucose in blood of animals $(x \pm S E, n=15)$ :

$\square$-control group of animals, $\square$-experimental group of animals

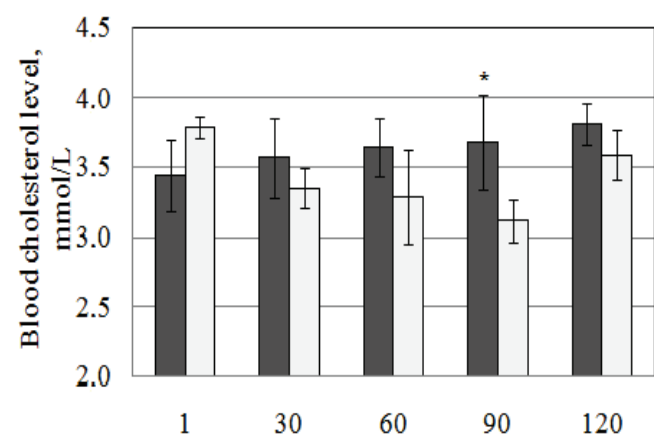

Fig. 2. The level of cholesterol in blood of animals $(x \pm S E, n=15)$ :

* $-\mathrm{P}<0.05$ at comparison with the parameters of the control group; see Fig. 1 


\section{Discussion}

This study demonstrated that the use of feed additive with organic iodine in the amount of $1.5 \mathrm{~g}$ per individual daily in feeding of the lactating cows during 60 days contributes to the activation of the hormoneforming functions of the thyroid, which is a stimulating factor for the intensification of the metabolic processes in the organism of animals.

The animals which received organic iodine were observed to have increase in the serum proteins, indicating absence of impaired metabolism. This is related to the fact that iodine introduced into the organism of animals positively affects the functioning of their thyroid, resulting in synthesis of hormones, most of which are bonded with blood proteins (Mellen \& Hardy, 1957; Bartalena \& Robbins, 1993; Power et al., 2000).

Different sections of the thyroid produce hormones directly involved in the phosphorus-calcium and mineral metabolism, and in particular are responsible for homeostasis and metabolism of calcium, phosphorus and magnesium (Mosekilde et al., 1990; Çaksen et al., 2003; Cardoso et al., 2014). Our study revealed increase in the parameters of mineral metabolism in the blood serum of cows which received organic iodine.

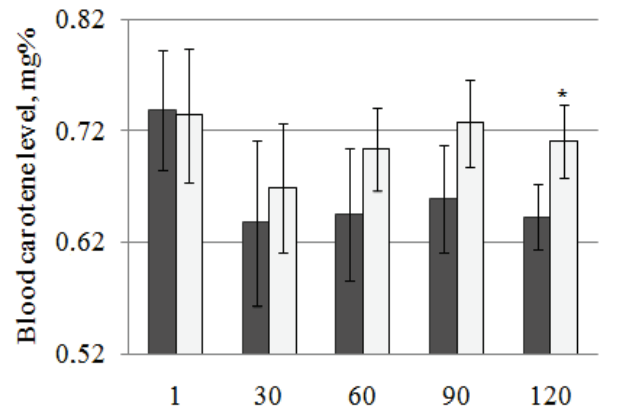

Fig. 3. Level of carotene in blood of animals $(x \pm S E, n=15)$ : see Fig. 2

Table 5

Parameters of dairy productivity $(\mathrm{x} \pm \mathrm{SE}, \mathrm{n}=15)$

\begin{tabular}{|c|c|c|c|c|c|c|c|c|}
\hline $\begin{array}{c}\text { Period of the expe- } \\
\text { riment }\end{array}$ & Group & Fat, $\%$ & Protein, \% & Lactose, $\%$ & Dry matter, \% & $\begin{array}{l}\text { Number of somatic } \\
\text { cells, thou } / \mathrm{cm}^{3}\end{array}$ & $\begin{array}{l}\text { Daily milk } \\
\text { yield, } \mathrm{kg}\end{array}$ & $\begin{array}{l}\text { Milk of } 4 \% \\
\text { fatness, } \mathrm{kg}\end{array}$ \\
\hline \multirow{2}{*}{ On the $1^{\text {st }}$ day } & I & $4.31 \pm 0.25$ & $3.05 \pm 0.14$ & $4.48 \pm 0.10$ & $12.22 \pm 0.30$ & $228 \pm 62$ & $31.5 \pm 2.7$ & $32.9 \pm 2.8$ \\
\hline & II & $4.48 \pm 0.29$ & $3.02 \pm 0.19$ & $4.53 \pm 0.11$ & $12.32 \pm 0.40$ & $189 \pm 53$ & $32.8 \pm 1.4$ & $35.2 \pm 1.5$ \\
\hline \multirow{2}{*}{ On the $30^{\text {th }}$ day } & I & $4.42 \pm 0.07$ & $3.11 \pm 0.09$ & $4.45 \pm 0.08$ & $12.36 \pm 0.20$ & $201 \pm 38$ & $33.4 \pm 1.7$ & $35.5 \pm 1.8$ \\
\hline & II & $4.47 \pm 0.11$ & $3.09 \pm 0.13$ & $4.56 \pm 0.05$ & $12.36 \pm 0.30$ & $197 \pm 33$ & $32.9 \pm 2.9$ & $35.2 \pm 3.1$ \\
\hline \multirow{2}{*}{ On the $60^{\text {th }}$ day } & I & $4.46 \pm 0.12$ & $3,14 \pm 0.07$ & $4.51 \pm 0.11$ & $12.36 \pm 0.20$ & $215 \pm 32$ & $32.9 \pm 1.9$ & $35.2 \pm 2.0$ \\
\hline & II & $4.59 \pm 0.09$ & $3.15 \pm 0.15$ & $4.59 \pm 0.10$ & $12.34 \pm 0.10$ & $174 \pm 41$ & $33.6 \pm 1.5$ & $36.6 \pm 1.6$ \\
\hline \multirow{2}{*}{ On the $90^{\text {th }}$ day } & I & $4.60 \pm 0.15$ & $3.16 \pm 0.06$ & $4.60 \pm 0.03$ & $12.35 \pm 0.10$ & $204 \pm 51$ & $31.2 \pm 3.6$ & $34.0 \pm 3.9$ \\
\hline & II & $4.63 \pm 0.10$ & $3.18 \pm 0.03$ & $4.62 \pm 0.06$ & $12.39 \pm 0.10$ & $146 \pm 48$ & $32.2 \pm 4.4$ & $35.2 \pm 4.8$ \\
\hline \multirow{2}{*}{ On the $120^{\text {th }}$ day } & I & $4.52 \pm 0.24$ & $3.14 \pm 0.15$ & $4.52 \pm 0.07$ & $12.28 \pm 0.40$ & $212 \pm 47$ & $27.5 \pm 2.5$ & $29.6 \pm 2.7$ \\
\hline & II & $4.58 \pm 0.30$ & $3.30 \pm 0.11$ & $4.63 \pm 0.06$ & $12.31 \pm 0.20$ & $167 \pm 54$ & $29.1 \pm 2.3$ & $31.6 \pm 2.5$ \\
\hline
\end{tabular}

Note: $* \mathrm{P}<0.05$ at comparison with the parameters of the control group.

Table 6

Parameters of the reproductive function $(x \pm S E, n=15)$

\begin{tabular}{lcccc}
\hline \multirow{2}{*}{ Parameters } & \multicolumn{4}{c}{ Groups } \\
\cline { 2 - 5 } & \multicolumn{2}{c}{ control } & \multicolumn{2}{c}{ experimental } \\
\hline Number of inseminations: & individuals & $\%$ & individuals & $\%$ \\
\cline { 2 - 5 } $1^{\text {st }}$ insemination & 7 & 46.7 & 9 & 60.0 \\
$2^{\text {nd }}$ insemination & 4 & 26.7 & 3 & 20.0 \\
$3^{\text {rd }}$ insemination & 3 & 20.0 & 3 & 20.0 \\
$4^{\text {th }}$ period & 1 & 6.6 & - & 0.0 \\
\hline Service-period, days & \multicolumn{2}{c}{$96.5 \pm 12.1$} & \multicolumn{2}{c}{$88.1 \pm 11.3$} \\
\hline Insemination index & \multicolumn{2}{c}{$1.90 \pm 0.18$} & \multicolumn{2}{c}{$1.60 \pm 0.22^{*}$} \\
\hline
\end{tabular}

Note: $* \mathrm{P}<0.05$ at comparison with the parameters of the control group.

The study demonstrates the increase in AST and ALT activities in the blood serum of lactating cows the diet of which included organic iodinecontaining feed. This to some extent allows us to diagnose the absence of disorders and dysfunctions of the liver for these enzymes are the main liver enzymes. The activity of this organ is related to the thyroid hormones which regulate the main metabolism of hepatocytes, the cells of the parenchyma of the liver, which in turn regulates endocrine functions of the thyroid hormones (Malik \& Hodgson, 2002; Chalasani et al., 2004; Moustafa et al., 2009; Mariani \& Berns, 2012). During our experiment, the animals which received organic iodine were observed to have a decrease in the de Ritis Coefficient. This parameter in lactating cows of the experimental and control groups was more than one, which could indicate intensified activity of the heart muscle, but is considered the norm for highly-productive animals (Lapteva \& Suvorov, 2018).

As a result of feeding the cows with an organic iodine-containing additive we determined increase in alkaline phosphatase in the blood of animals of the experimental group. This parameter is an indicator according to which one can judge the cell penetrability, regulation of fat and protein metabolisms, and also the digestion of mineral substances from the blood by the tissues (Wei et al., 2004). Increase in the content of glucose in the blood of the experimental group of cows indicates an increase in the process of gluconeogenesis, which mainly occurs in the liver, the functioning of which, as described above, is closely related to the correct functioning of the thyroid (Sinha et al., 2014; Jayanthi \& Srinivasan, 2019).
Decrease in the cholesterol level in the blood of lactating cows which received organic iodine represents the activity of hormones of the thyroid towards the increase of lypolysis, implicating decrease in the concentration of cholesterol and triglycerides in the blood (Shin \& Osborne, 2003; Gagnon et al., 2010). Furthermore, this indicates insufficient production of thyroxine hormone which activates the enzyme which, in turn, regulates the intensity of the cholesterol synthesis (Angelin et al., 2015; Balabaev \& Derho, 2017).

Increase in the content of carotene was determined in the blood serum of animals which received the additive with organic iodine, representing increase in the vitamin metabolism in lactating cows. This may be an indicator of normal hormone-producing function of the thyroid (Zimmermann et al., 2007; Al-Rubae'I \& Al-Musawi, 2011; Gunchak \& Grimak, 2014).

The obtained results of the study indicate the correspondence of the action of the proposed iodine additive to the actions of the existing analogues (Krasnoslobodceva, 2010; Moschini et al., 2010; Gorlov et al., 2014; Bykova et al., 2017). Moreover, according to data of control milkings, we determined an increase in the dairy productivity and quality parameters of milk from cows of the experimental group, where the animals received organic iodine, compared with the control animals. Use of the feed with organic iodine led to the $3.9 \%$ increase in the daily yield of milk with $4.0 \%$ fat, $2.9 \%$ increase in the milk protein and reduction of NSC measuring $19.1 \%$ on the 60th day, and the tendency towards improvement of some parameters of dairy productivity remained also on the 90th day (milk yield of milk with $4.0 \%$ was $3.5 \%$ higher, NSC decreased by $28.4 \%$ ). As a result of the effect of the additive, on the 120th day of the experiment the amount of the milk yield from the lactating cows of the experimental group exceeded the control values by $6.8 \%$, and the content of milk fat was $5.1 \%$ higher at decrease in NSC by $21.2 \%$. This indicates the fact that sufficient production of thyroid hormones positively correlates with the parameters of the dairy productivity of cows in the biosynthesis of the constituents of milk (Blum et al., 1983; Krasnoslobodceva, 2010).

The hormone regulation of the thyroid is known to directly affect the reproductive function of animals. The hormones of the thyroid have a stimulating effect on the differentiation of the ovarian follicles and intensify the production of luteinizing hormone which contributes to ovulation, formation of the corpus luteum and the development of the embryo (Pop- 
pe et al., 2007; Balabaev \& Derho, 2016). According to the results of our studies, we found an improvement of the reproductive function of cows which received organic iodine compared with the animals of the control group: the parameters of the service-period and index of insemination of the animals which received the organic iodine-containing additive reduced by $8.5 \%$ and $15.8 \%$ respectively. This characterizes the surveyed additive as an efficient preparation for improvement of physiological-biochemical parameters of the organism and productive qualities of the animals.

It should be noted that in the 30 days after finishing the feeding with the fodder with organic iodine, the animals of the experimental group were observed to experience the continuing effect of the additive, i.e. higher values of the biochemical parameters of blood, increase in dairy productivity and improvement of the reproductive qualities compared with such of the control.

\section{Conclusion}

Thus, as a result of the research conducted, we determined that use of feed with organic iodine in the amount of $1.5 \mathrm{~g}$ per individual in the feeding of lactating cows over 60 days contributed to uniform ingression of iodine into the organism of animals and increased in its parameter in the blood serum. Furthermore, according to the results showing an increase in the parameters of all types of metabolism in the organism of animals which received the feed with organic iodine, we can presume that the additive has an effect on the hormone-producing function of the thyroid. It was found that all these factors together had a positive effect not only on the increase in the parameters of dairy productivity of animals which received organic iodine in the additive but also on their reproductive function. Nonetheless, to recommend this feed as a preparation which helps eliminate iodine-deficiency in feeding cows and for accurate analysis of its impact on the hormone-producing function of the thyroid of animals, further studies on the level of thyroid hormones in blood are needed.

\section{References}

Al-Rubae'i, S. H., \& Al-Musawi, A. K. (2011). An evaluation of antioxidants and oxidative stress in Iraqi patients with thyroid gland dysfunction. African Journal of Biochemistry Research, 5(7), 188-196.

Angelin, B., Kristensen, J. D., Eriksson, M., Carlsson, B., Klein, I., Olsson, A. G. Chester Ridgway, E., \& Ladenson, P. W. (2015). Reductions in serum levels of LDL cholesterol, apolipoprotein B, triglycerides and lipoprotein (a) in hypercholesterolaemic patients treated with the liver-selective thyroid hormone receptor agonist eprotirome. Journal of Internal Medicine, 277(3), 331-342.

Balabaev, B. K., \& Derho, M. A. (2017). Ocenka vzaimosvyazi gormonov shchitovidnoj zhelezy i pokazatelej lipidnogo obmena u remontnyh telok [Assessing the relationship of thyroid hormones and lipid metabolism in repair heifers]. AIC of Russia, 24(1), 175-180 (in Russian).

Bartalena, L., \& Robbins, J. (1993). Thyroid hormone transport proteins. Clinics in Laboratory Medicine, 13(3), 583-598.

Blum, J. W., Kunz, P., Leuenberger, H., Gautschi, K., \& Keller, M. (1983). Thyroid hormones, blood plasma metabolites and haematological parameters in relationship to milk yield in dairy cows. Animal Science, 36(1), 93-104.

Bykova, E. V., Korobov, A. P., \& Gumenyuk, A. P. (2017). Vliyanie organicheskogo mikroelementnogo kompleksa joda OMEK-J na metabolicheskie processy v organizme dojnyh korov [The influence of the organic trace element complex of iodine OMEC-J on metabolic processes in the body of dairy cows]. Agricultural Scientific Journal, 6, 3-6 (in Russian).

Çaksen, H., Dülger, H., Cesur, Y., Atas, B., Tuncer, O., \& Odabas, D. (2003). Evalution of thyroid and parathyroid functions in children receiving long-term carbamazepine therapy. International Journal of Neuroscience, 113(9), 1213-1217.

Cardoso, L. F., Maciel, L. M., \& de Paula, F. J. (2014). The multiple effects of thyroid disorders on bone and mineral metabolism. Arquivos Brasileiros de Endocrinologia and Metabologia, 58(5), 452-463.

Chalasani, N., Aljadhey, H., Kesterson, J., Murray, M. D., \& Hall, S. D. (2004). Patients with elevated liver enzymes are not at higher risk for statin hepatotoxicity. Gastroenterology, 126(5), 1287-1292.

Flachowsky, G., Franke, K., Meyer, U., Leiterer, M., \& Schöne, F. (2014). Influencing factors on iodine content of cow milk. European Journal of Nutrition, 53(2), 351-365.

Fuge, R. (2013). Soils and iodine deficiency. In: Essentials of medical geology. Springer, Dordrecht. Pp. 417-432.
Gagnon, A., Antunes, T. T., Ly, T., Pongsuwan, P., Gavin, C., Lochnan, H. A., \& Sorisky, A. (2010). Thyroid-stimulating hormone stimulates lipolysis in adipocytes in culture and raises serum free fatty acid levels in vivo. Metabolism, 59(4), 547-553.

Gorlov, I. F., Mosolova, N. I., Zlobina, E. Y., Korotkova, A. A., \& Prom, N. A. (2014). Use of new supplement feeds based on organic iodine in rations of lactating cows. American-Eurasian Journal of Agricultural and Environmental Sciences, 14(5), 401-406.

Gunchak, V. M., \& Grimak, Y. I. (2014). Jodnaya nedostatochnost' i korrekciya reproduktivnoj funkcii korov preparatami joda [Iodine deficiency and correction of the reproductive function of cows with iodine preparations]. Scientific Bulletin of the Lviv National University of Veterinary Medicine and Biotechnology Named after S. Z. Gzhitsky, 16, 23-41.

Hu, Q. H., Moran, J. E., \& Gan, J. Y. (2012). Sorption, degradation, and transport of methyl iodide and other iodine species in geologic media. Applied Geochemistry, 27(3), 774-781.

Hunchak, R. V., Sedilo, H. M., Kystsiv, V. O., Gutyj, B. V., \& Hunchak, V. M. (2018). Total liquid maintenance and correlation of their classes in the sow's colostrum and milk at different levels of aquacart of iodine in their rations. Ukrainian Journal of Ecology, 8(1), 644-648.

Jayanthi, R., \& Srinivasan, A. R. (2019). Biochemical isthmus [nexus] between type 2 diabetes mellitus and thyroid status - an update. Diabetes and Metabolic Syndrome: Clinical Research and Reviews, 13(2), 1173-1177.

Kalashnikov, A. P., Fisinin, V. I., Shcheglov, V. V., Klejmenov, N. I. (Eds.). (2003). Normy i raciony kormleniya sel'skohozyajstvennyh zhivotnyh [Norms and diets for feeding farm animals]. Znanie, Moscow (in Russian).

Kondrahin, I. P. (2004). Metody veterinarnoj i klinicheskoj laboratornoj diagnostiki [Methods of veterinary and clinical laboratory diagnostics]. KolosS, Moscow (in Russian).

Krasnoslobodceva, A. S. (2010). Aprobaciya sistemy kormleniya vysokoproduktivnyh korov s ispol'zovaniem selen i jodosoderzhashchih preparatov organicheskoj formy [Testing the feeding system of highly productive cows using selenium and iodine-containing organic form preparations]. Bulletin of Russian Universities, Mathematics, 15(1), 135-137 (in Russian).

Lapteva, E. I., \& Suvorov, B. V. (2018). Vliyanie kormovogo bentonita i avtolizata drozhzhej na aminotransferazy krovi korov pri alimentarnoj osteodistrofii [The effect of fodder bentonite and yeast autolysate on aminotransferases of cow blood during alimentary osteodystrophy]. Contribution of Young Scientists to Agricultural Science. Pp. 190-192 (in Russian).

Leung, A. M., Braverman, L. E., \& Pearce, E. N. (2012). History of US iodine fortification and supplementation. Nutrients, 4(11), 1740-1746.

Liu, D., Lin, X., Yu, F., Zhang, M., Chen, H., Bao, W., \& Wang, X. (2015). Effects of 3,5-diiodotyrosine and potassium iodide on thyroid function and oxidative stress in iodine-excess wistar rats. Biological Trace Element Research, 168(2), 447-452.

Malik, R., \& Hodgson, H. (2002). The relationship between the thyroid gland and the liver. QJM: An International Journal of Medicine, 95(9), 559-569.

Mariani, L. H., \& Berns, J. S. (2012). The renal manifestations of thyroid disease. Journal of the American Society of Nephrology, 23(1), 22-26.

Mellen, W. J., \& Hardy Jr., L. B. (1957). Blood protein-bound iodine in the fowl. Endocrinology, 60(4), 547-551.

Moschini, M., Battaglia, M., Beone, G. M., Piva, G., \& Masoero, F. (2010). Iodine and selenium carry over in milk and cheese in dairy cows: Effect of diet supplementation and milk yield. Animal, 4(1), 147-155.

Mosekilde, L., Eriksen, E. F., \& Charles, P. (1990). Effects of thyroid hormones on bone and mineral metabolism. Endocrinology and Metabolism Clinics of North America, 19, 35-63.

Moustafa, A. H. A., Ali, E. M., Mohamed, T. M., \& Abdou, H. I. (2009). Oxidative stress and thyroid hormones in patients with liver diseases. European Journal of Internal Medicine, 20(7), 703-708.

National Research Council (2001). Nutrient requirements of dairy cattle: Seventh revised edition. The National Academies, Washington.

Nudda, A., Battacone, G., Decandia, M., Acciaro, M., Aghini-Lombardi, F., Frigeri, M., \& Pulina, G. (2009). The effect of dietary iodine supplementation in dairy goats on milk production traits and milk iodine content. Journal of Dairy Science, 92(10), 5133-5138.

Pattanaik, A. K., Khan, S. A., \& Goswami, T. K. (2011). Iodine supplementation to a diet containing Leucaena leucocephala leaf meal: Consequences on nutrient metabolism, clinical chemistry and immunity of goats. Animal Production Science, 51(6), 541-548.

Petrov, A. K., \& Gnezdilova, L. A. (2015). Dejstvie jodsoderzhashchih preparatov na biohimicheskie pokazateli krovi i otkormochnye kachestva molodnyaka ovec [The effect of iodine-containing drugs on the biochemical parameters of blood and the feeding qualities of young sheep]. Bulletin of the Peoples' Friendship University of Russia, Series Agronomy and Livestock, 1, 48-54 (in Russian).

Poppe, K., Velkeniers, B., \& Glinoer, D. (2007). Thyroid disease and female reproduction. Clinical Endocrinology, 66(3), 309-321. 
Power, D. M., Elias, N. P., Richardson, S. J., Mendes, J., Soares, C. M., \& Santos, C. R. A. (2000). Evolution of the thyroid hormone-binding protein, transthyretin. General and Comparative Endocrinology, 119(3), 241-255.

Rasmussen, L. B., Schomburg, L., Köhrle, J., Pedersen, I. B., Hollenbach, B., Hög, A., Ovesen, L., Perrild, H., \& Laurberg, P. (2011). Selenium status, thyroid volume, and multiple nodule formation in an area with mild iodine deficiency. European Journal of Endocrinology, 164(4), 585-590.

Rey-Crespo, F., López-Alonso, M., \& Miranda, M. (2014). The use of seaweed from the Galician coast as a mineral supplement in organic dairy cattle. Animal, 8(4), 580-586.

Romanenko, L. V., Volgin, V. I., \& Fedorova, Z. L. (2014). Strategiya pitaniya vysokoproduktivnyh golshtinizirovannyh korov chernopestroj porody [Strategy of feeding high production Holstein cows of the Black-flecked breed]. Dairy and Meat Cattle Breeding, 6, 34-36 (in Russian).

Shin, D. J., \& Osborne, T. F. (2003). Thyroid hormone regulation and cholesterol metabolism are connected through sterol regulatory element-binding protein2 (SREBP-2). Journal of Biological Chemistry, 278(36), 34114-34118.

Sinha, R. A., Singh, B. K., \& Yen, P. M. (2014). Thyroid hormone regulation of hepatic lipid and carbohydrate metabolism. Trends in Endocrinology and Metabolism, 25(10), 538-545.

Vavilina, A. V., \& Rybkin, V. S. (2013). Gigienicheskaya ocenka soderzhaniya joda $v$ okruzhayushchej srede (obzor) [Hygienic assessment of iodine content in the environment (review)]. Astrakhan Bulletin of Environmental Education, 23, 177-181 (in Russian).
Vereshchak, N. A., Sokolova, O. V., Belousov, A. I., \& Krasnoperoe, A. S. (2012). Korrekciya joddeficitnogo sostoyaniya u vysokoproduktivnyh korov s primeneniem kormovoj dobavki "Joddar" [Correction of iodine deficiency in high production cows with the use of feed additive "Ioddar"]. Agrarian Bulletin of the Ural, 102, 13-14 (in Russian).

Voogt, W., Holwerda, H. T., \& Khodabaks, R. (2010). Biofortification of lettuce (Lactuca sativa L.) with iodine: The effect of iodine form and concentration in the nutrient solution on growth, development and iodine uptake of lettuce grown in water culture. Journal of the Science of Food and Agriculture, 90(5), 906-913.

Wei, W., Zheng-Zhong, B., Yong-Jie, W., Qing-Wu, Z., \& Ya-Lin, M. (2004). Bioeffects of low-frequency ultrasonic gene delivery and safety on cell membrane permeability control. Journal of Ultrasound in Medicine, 23(12), 1569-1582.

Weng, H. X., Liu, H. P., Li, D. W., Ye, M., Pan, L., \& Xia, T. H. (2014). An innovative approach for iodine supplementation using iodine-rich phytogenic food. Environmental Geochemistry and Health, 36(4), 815-828.

Zimmermann, M. B., \& Boelaert, K. (2015). Iodine deficiency and thyroid disorders. The Lancet Diabetes and Endocrinology, 3(4), 286-295.

Zimmermann, M. B., Jooste, P. L., Mabapa, N. S., Schoeman, S., Biebinger, R, Mushaphi, L. F., \& Mbhenyane, X. (2007). Vitamin A supplementation in iodine-deficient African children decreases thyrotropin stimulation of the thyroid and reduces the goiter rate. The American Journal of Clinical Nutrition, 86(4), 1040-1044. 